\title{
Economic Optimization of the Oil and Gas Companies Financing
}

\author{
Safiullin Lenar Nailevich ${ }^{1}$, Bulatova Elvira Ildarovna ${ }^{1}$, Fathutdinova Regina Andreevna ${ }^{1}$, Surkova Sofia Mirgalimovna ${ }^{2}$ \\ ${ }^{1}$ Doctor of Economics, Professor, Kazan Federal University, Kazan Federal University, \\ Scopus ID 55694209500, ORCID 0000-0002-1748-3964 \\ ${ }^{2}$ Candidate of Economic Sciences, Associate Professor, Kazan Federal University, \\ Scopus ID 57192265030, ORCID 0000-0002-6523-7194, Kazan Federal University \\ ${ }^{3}$ Master of the Institute of Management, Economy and Finance, Kazan Federal University, \\ ORCID 0000-0002-3325-6729, Kazan Federal University \\ ${ }^{4}$ Candidate of Economic Sciences, Associate Professor, Kazan Federal University, \\ The University of Management "TISBI” (Kazan)
}

\begin{abstract}
In the current realities of financial technology development, it is necessary to move from traditional ways of financing companies' activities to more transparent, fast and efficient ones. The article reveals the distinctive features of the oil and gas business of the Russian Federation, in particular, the realities of the development of this industry in the face of foreign economic shocks in the form of sanctions. The oil and gas business and companies in this industry are significant not only within the country, but also on the international market as participants in export-import, finance, investment, political and other types of relations. The availability of such fuel and energy resources within the country allows it to be in a certain degree in high positions on the world market, since companies in the industry accumulate a significant amount of capital in their foreign trade and foreign economic activities and, to a certain extent, ensure the movement of foreign currency within the framework of their trade and economic relations. The authors of the article calculated an economic and mathematical model based on the structural-dynamic and coefficient analysis, that allows determining the feasibility of forming a new digital tool for oil and gas projects financing. In the course of the analysis, based on Russian quarterly data for 2015-2018, the connection between the level of overdue debt on oil companies
\end{abstract}

loans and the development indicators of the Russian oil and gas business was determined. The main conclusions presented in the article can be used in scientific and practical activities in order to develop financial and credit technologies used in the oil and gas business.

Keywords: Oil And Gas Business, Sources Of Financing, Level Of Overdue Debt, Economic And Mathematical Modeling.

\section{INTRODUCTION}

The sources of financing used by oil and gas companies for their projects allow them operating efficiently.

The year of 2014 was marked by sanctions against oil and gas companies and a number of international projects was also closed, in particular, the rapid fall in oil prices due to the "shale revolution" in the United States happened. This aspect was associated with the growth of supply in the world oil market and the demand for fuel and energy resources that did not keep up with it.

US oil and gas companies, namely those engaged in shale oil production, have reduced their dependence on external fundraising by the end of 2018 (Fig. 1). 
International Journal of Engineering Research and Technology. ISSN 0974-3154, Volume 13, Number 11 (2020), pp. $3485-3496$

(C) International Research Publication House. https://dx.doi.org/10.37624/IJERT/13.11.2020.3485-3496

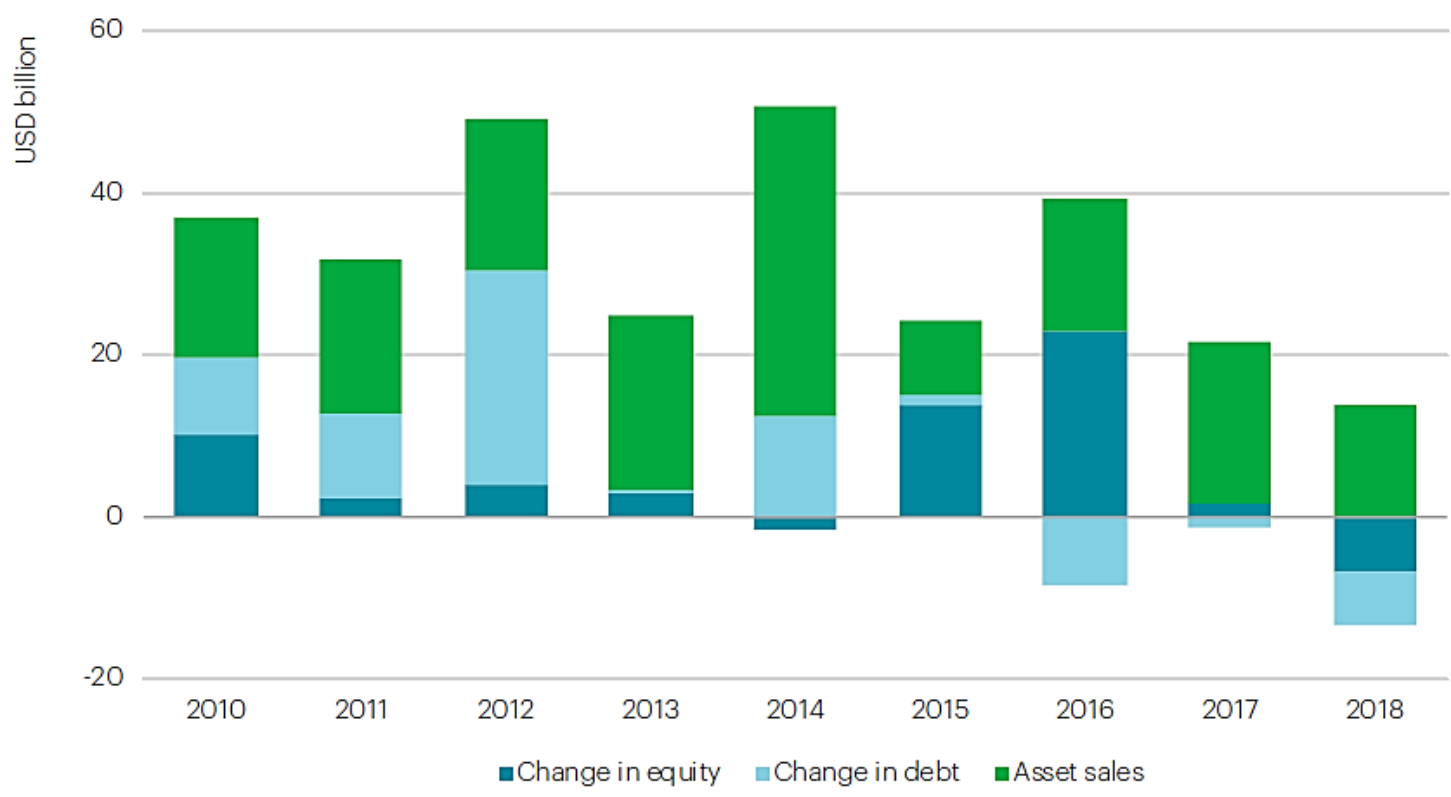

Fig. 1. US E\&P independents indicative source of finance [1]

Note: Includes data on 48 US E\&P independent companies.

Source: IEA analysis with calculations based on company filings and Bloomberg (2019), Bloomberg Terminal.

Considering the sources of funding for these companies, one can identify certain time periods (Table 1) [2].

Table 1. Time periods for financing the activities of the US oil and gas companies

\begin{tabular}{|c|c|}
\hline Period & Characteristics \\
\hline $2010-2014$ & $\begin{array}{r}\text { The need to use external sources for financing: debt obligations and proceeds from the sale of } \\
\text { non-core assets, bank syndicated renewable loans secured by oil and gas reserves }\end{array}$ \\
\hline $2015-2016$ & $\begin{array}{r}\text { Credit organizations stopped lending to companies in the US industry due to the collapse in } \\
\text { prices on the world market, decrease in asset sales by } 70 \% \text { and the need to attract more } \\
\text { expensive capital }\end{array}$ \\
\hline 2017 & Asset sales are again the main source of financing \\
\hline
\end{tabular}

In 2018, free cash flow reached almost 90 billion USD, which has not happened since 2008. During 2014-2018 period, large companies maintained a high level of dividends compared to other industries, distributing on average about 50 billion USD per year to shareholders.
In addition to the above, it is noted that in 2018, the financial condition of oil and gas companies tended to noticeably improve (Fig. 2) 


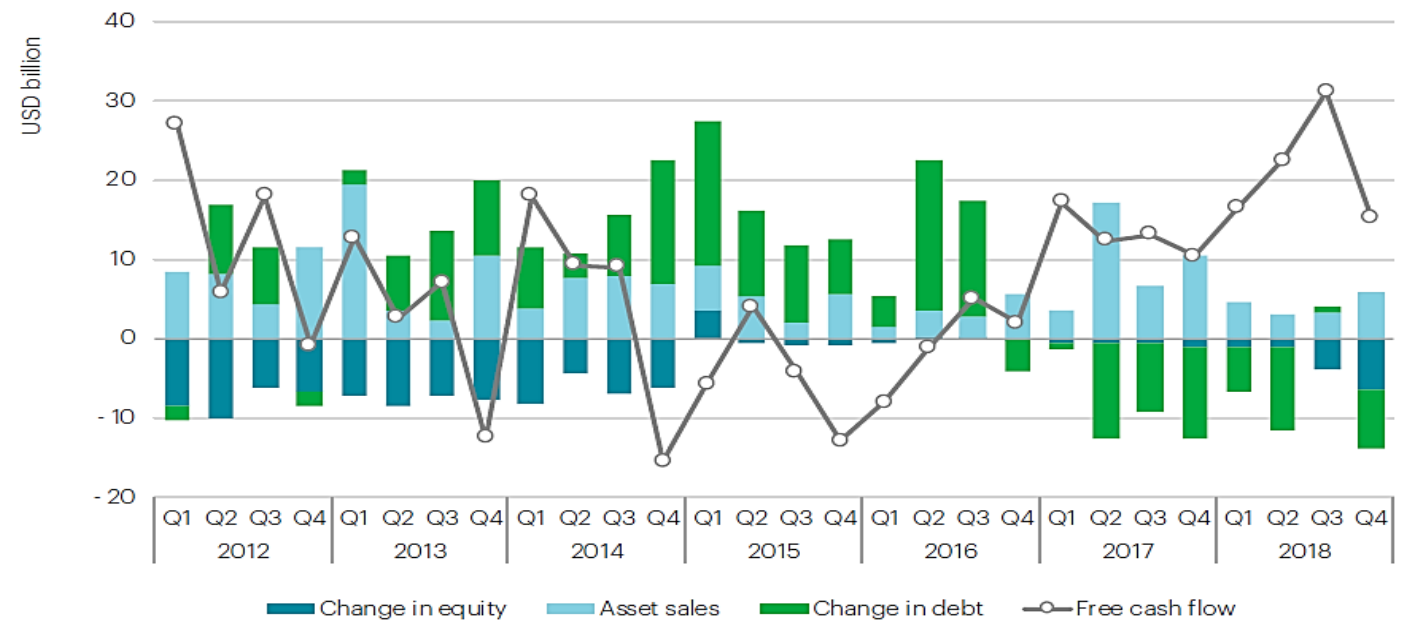

Fig.2. Majors indicative source of finance and free cash flow

Note: Free cash flow is cash from operating activities less capital expenditure. It excludes change in working capital.

Source: IEA analysis with calculations based on company filings and Bloomberg (2019), Bloomberg Terminal.

The USA, as the country that became the founder of the "shale revolution", has a different model of financing the production of shale oil from the classic one [3]. The industry in the country itself is characterized by negative free cash flow, because the constant expectations of market participants in the growth of production and cost optimization caused constant overspending in the sector. At the same time, the US shale industry is dominated by small and medium-sized independent producers, which is radically different from the model of the Russian Federation, where the major of the oil and gas business are vertically integrated oil companies (VIOC).

Russian companies in the oil and gas sector do not have competitive R\&D financing as an investment in innovation. An important aspect of foreign experience in financing innovative projects in the economy's oil and gas sector is the use of venture funds (Shell

\begin{abstract}
Technology Ventures, BP Ventures, Chevron Technology Ventures etc.) [4].

In addition to the significant amount of government support in the US oil and gas industry, one of the unique components is the lack of dominance of national oil companies, as can be seen in a number of OPEC countries [5].

When comparing groups of companies such as Russian VIOCs, US shale companies, and multinational VIOCs in terms of weighted average interest rates (Fig.3), one can notice that the interest rate of Russian VIOCs is close to the interest rates of shale companies, although taking into account the development of their foreign trade and foreign economic activities, the scale of the company itself, Russian vertically integrated oil companies should have lower interest rates and a longer period of financing compared to the other two groups.
\end{abstract}

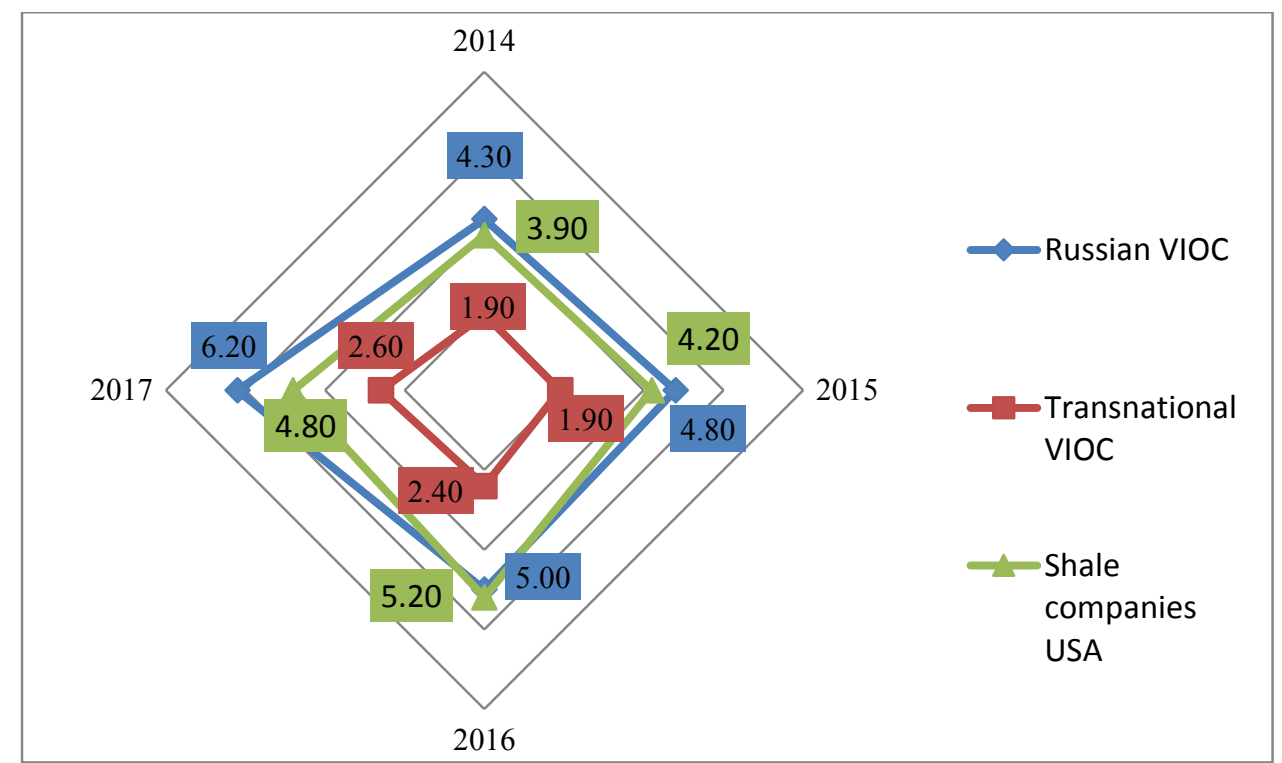

Fig.3. Weighted average interest rate for groups of oil and gas companies in 2014-2017, \% [6] 
International Journal of Engineering Research and Technology. ISSN 0974-3154, Volume 13, Number 11 (2020), pp. $3485-3496$

(C) International Research Publication House. https://dx.doi.org/10.37624/IJERT/13.11.2020.3485-3496

At the same time, Russian VIOCs are characterized by a significant share of short-term financing (Fig.4), with the inability to invest in the development of the company, especially under the existing tax regime, the high cost of debt capital, restrictions on attracting external forms of financing for its activities, which also limits the potential for opening new fields.

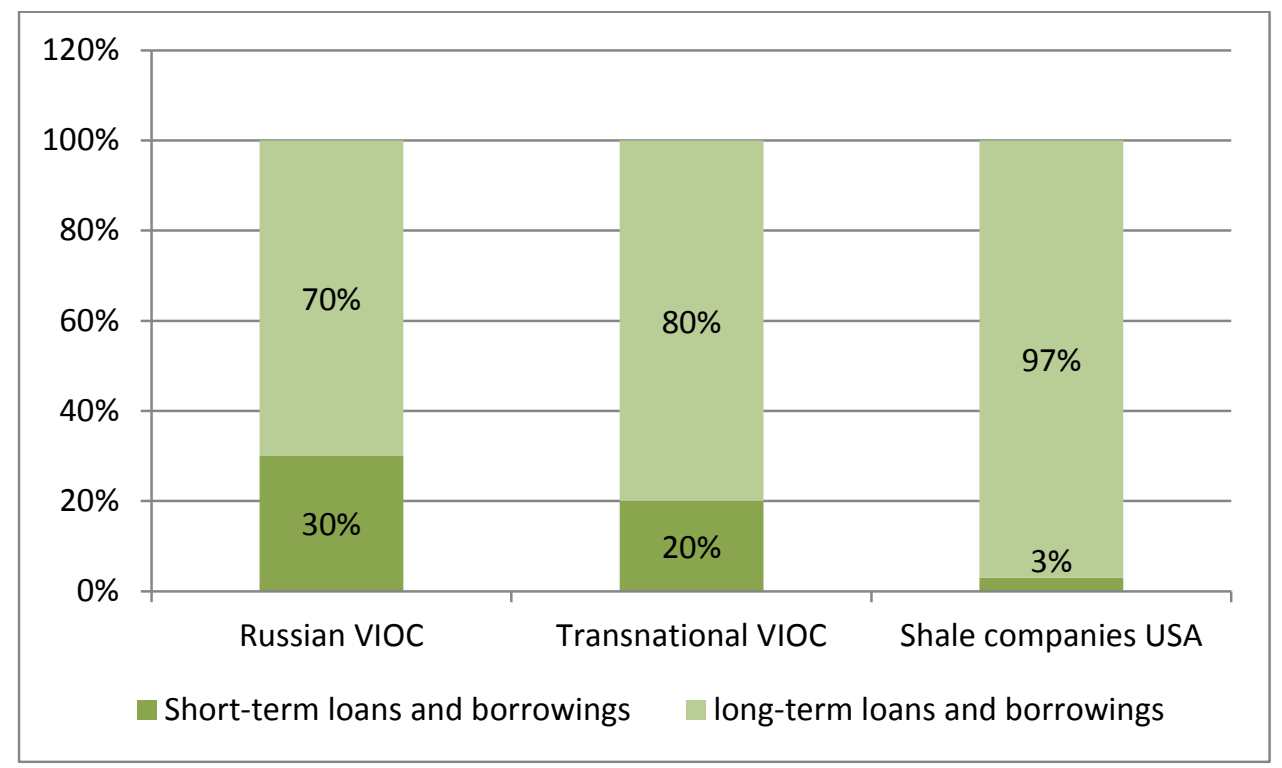

Fig.4. Ratio of specific short-term and long-term loans by group of companies, $\%$

Russian oil and gas companies are characterized by less significant investment in $\mathrm{R} \& \mathrm{D}$ compared to foreign companies in this industry.

Effective promotion of investment in $R \& D$ is determined by the clusters and technology parks creation, technology centers, positive experience abroad of which is also being adopted by the Russian oil and gas complex. Gazprom Neft, one of Russia's vertically integrated oil and gas companies, is implementing digital projects as part of its R\&D activities.
2018 was one of the most successful years for Russian oil and gas companies in their history. An abnormal combination of high oil prices and a weak ruble against the background of high export duties caused a rapid increase in their financial indicators and, as a result, their capitalization. Also, the ongoing "trade wars", combined, have had an impact on the performance of Russian oil and gas companies. These aspects are confirmed by a coefficient analysis (Fig.57) of the performance indicators of oil and gas VIOCs in the Russian Federation.

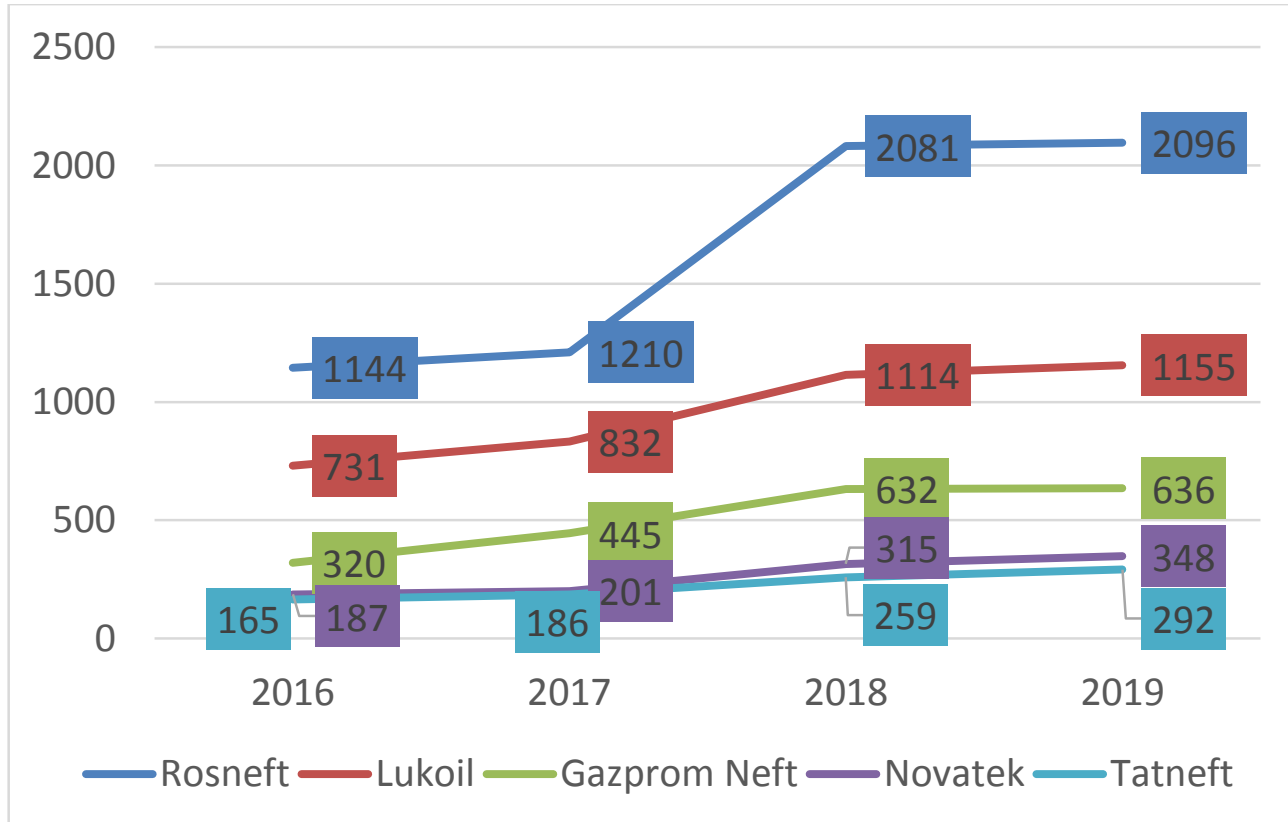

Fig.5. EBITDA of oil and gas companies in the Russian Federation in dynamics, billion rub. [6] 
International Journal of Engineering Research and Technology. ISSN 0974-3154, Volume 13, Number 11 (2020), pp. 3485-3496

(C) International Research Publication House. https://dx.doi.org/10.37624/IJERT/13.11.2020.3485-3496

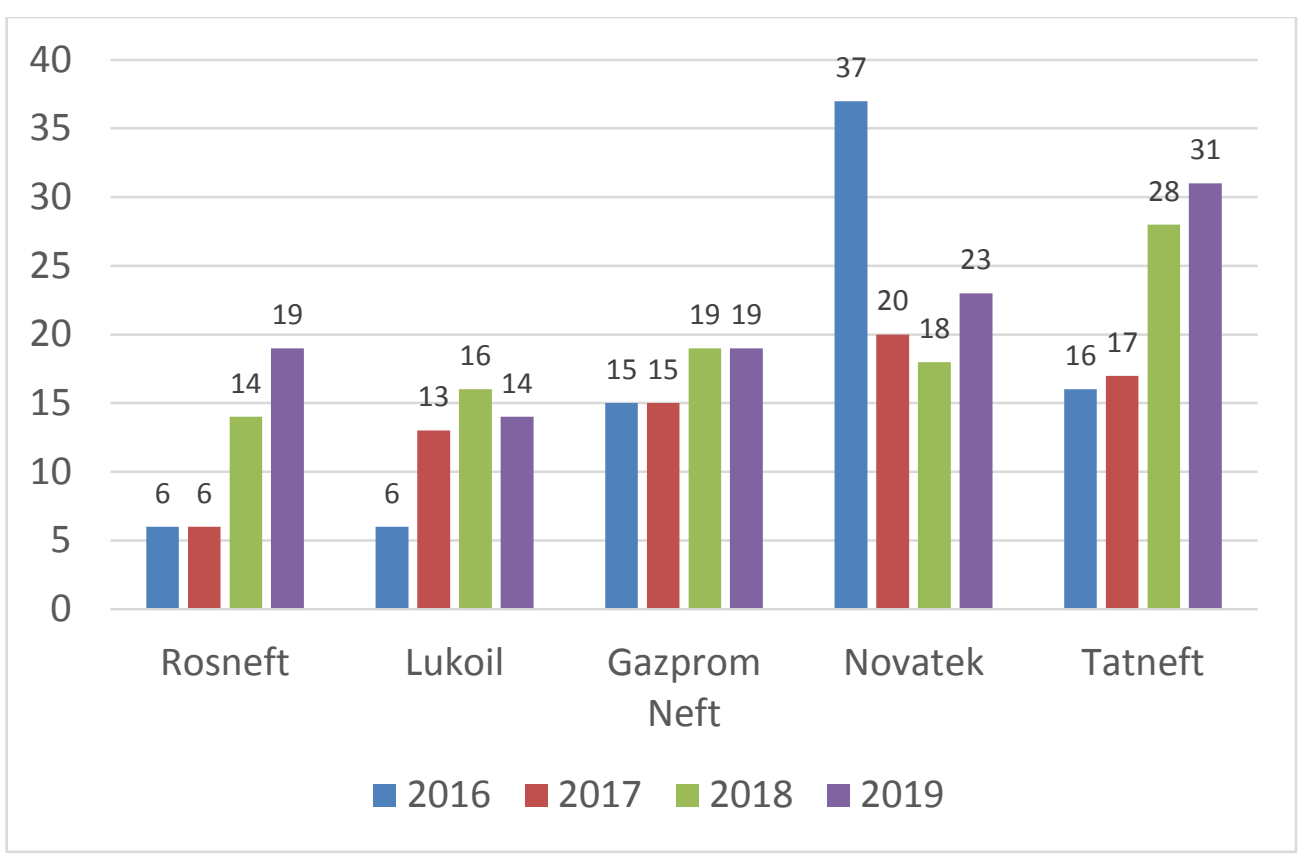

Fig. 6. ROE indicator of oil and gas companies in the Russian Federation in dynamics, \% [6]

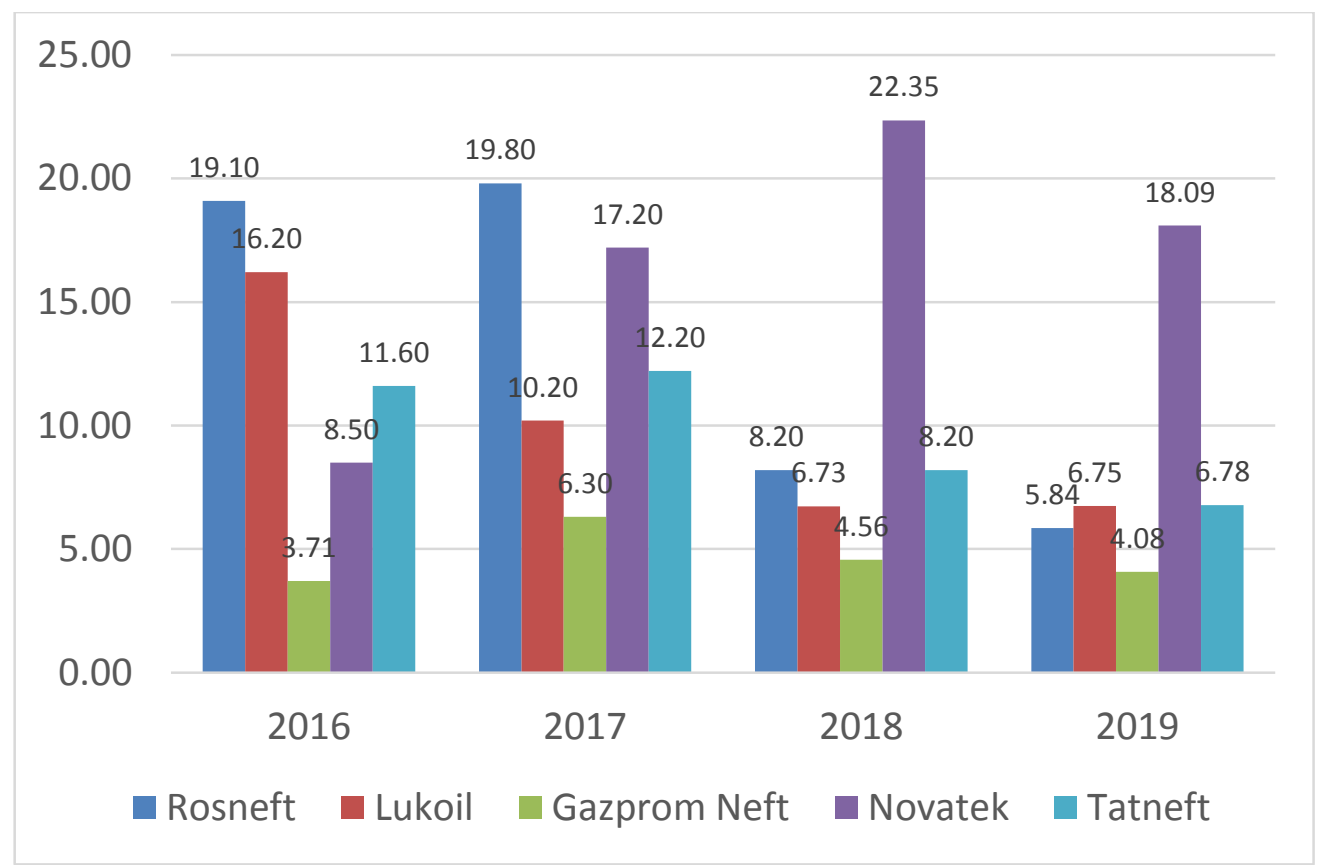

Fig. 7. P/E indicator of oil and gas companies in the Russian Federation in dynamics [6]

The favorable state of the oil and gas business of the Russian Federation according to the results of 2018 actualizes the definition of a retrospective aspect in relation to the most popular instruments for financing activities used in the context of external economic shocks emergence in the form of sanctions. Thus, the relevance is defined.

Under the imposed sanctions, oil and gas companies were barred from the possibility of obtaining foreign sources of financing, in particular, the possibility of acquiring the necessary imported components.

In addition to project-based syndicated lending and the use of state support in financing large oil and gas projects, Russian realities demonstrate a significant share of borrowing in the industry (according to statistics from the Bank of Russia website) and more than $30 \%$ of the oil and gas production companies in the Russian bond market [7]. 
The level of overdue debt (Fig.8), expressed in relation of the mining industry overdue loans to the total volume of loans issued, shows significant volatility and a sharp increase by the end of 2015, which can be more described by the impact of sanctions processes on the activities of companies and the need to reorient financial resources for activities from foreign loans to national ones. At the same time, it should be noted that during the period of significant sanctions development, companies could repay previously received loans.

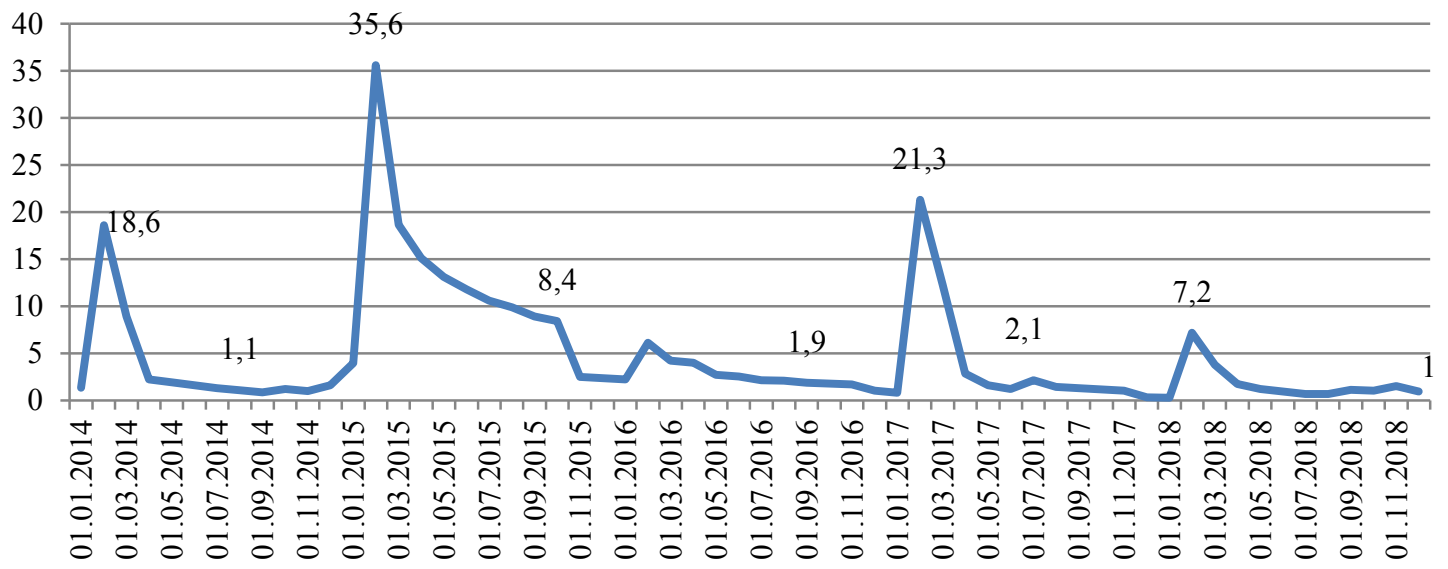

Fig.8. The level of overdue debt on loans to the mining industry (including oil and gas companies), \%

In particular, bond issuance, along with lending, is the most common source of financing for oil and gas companies in Russia.

\section{METHODS}

In this article, the authors applied methods of structural and dynamic analysis, tabulation, graphical analysis, abstraction, hypothesis setting, correlation, regression modeling, verification for approximation, heteroscedasticity, autocorrelation of residuals, prediction, coefficient analysis, construction of a graphical model of token issuance, in particular, methods of scientific knowledge.

To determine the feasibility of forming a new tool for financing oil and gas business projects, the authors put hypotheses, the confirmation of which justifies the need for further analysis.
Hypothesis 1: level of overdue debt in the total volume of lending to Russian economy companies in the oil and gas sector will remain at the same level by 2021 compared to the data at the beginning of 2018, or will increase by $10-15 \%$.

Hypothesis 2: if certain adverse aspects occur during the verification of hypothesis 1, an additional test of interest in the oil and gas industry of the Russian Federation is performed by determining the positive trend of the Moscow Exchange MOEXOG industry index.

There are sixteen observation points for the simulation - the period from 2015 to 2018 by quarter. Factors defined for all stages of modeling in the number of 22 are presented in Table 2. The average values of each of the factors in the quarterly range were determined.

Table 2. Input parameters for modeling the level of overdue debt on loans of Russian oil and gas companies $[8,9,10,11]$

\begin{tabular}{|c|c|c|c|}
\hline & Variables & Data type & Source \\
\hline $\mathrm{Y}$ & Overdue debt level & $\%$ & Bank of Russia \\
\hline $\mathrm{X} 1$ & $\begin{array}{c}\text { Average crude oil production (including gas } \\
\text { condensate) }\end{array}$ & thousand tons & Federal statistics service \\
\hline $\mathrm{X} 2$ & Quantity of exported crude oil & million tons & Federal statistics service \\
\hline $\mathrm{X} 3$ & Exported crude oil value & million dollars & Federal statistics service \\
\hline $\mathrm{X} 4$ & Average export prices (crude oil) & $\begin{array}{c}\text { USD per } \\
\text { barrel }\end{array}$ & Federal statistics service \\
\hline
\end{tabular}


International Journal of Engineering Research and Technology. ISSN 0974-3154, Volume 13, Number 11 (2020), pp. $3485-3496$

(C) International Research Publication House. https://dx.doi.org/10.37624/IJERT/13.11.2020.3485-3496

\begin{tabular}{|c|c|c|c|}
\hline & Variables & Data type & Source \\
\hline $\mathrm{X} 5$ & Quantity of exported petroleum products & million tons & Federal statistics service \\
\hline $\mathrm{X} 6$ & Cost of exported petroleum products & million dollars & Federal statistics service \\
\hline $\mathrm{X} 7$ & Average export prices (petroleum products) & $\begin{array}{c}\text { USD per } \\
\text { barrel }\end{array}$ & Federal statistics service \\
\hline $\mathrm{X} 8$ & Natural gas quantity - exported & $\begin{array}{l}\text { billion cubic } \\
\text { meters }\end{array}$ & Federal statistics service \\
\hline X9 & Exported natural gas value & million dollars & Federal statistics service \\
\hline $\mathrm{X} 10$ & Average export prices (natural gas) & $\begin{array}{l}\text { dollars per } \\
\text { thousand } \\
\text { cubic meters }\end{array}$ & Federal statistics service \\
\hline $\mathrm{X} 11$ & Quantity of liquefied natural gas - exported & $\begin{array}{l}\text { billion cubic } \\
\text { meters }\end{array}$ & Federal statistics service \\
\hline $\mathrm{X} 12$ & Exported liquefied natural gas value & million dollars & Federal statistics service \\
\hline $\mathrm{X} 13$ & Average export prices (liquefied natural gas) & $\begin{array}{l}\text { dollars per } \\
\text { thousand } \\
\text { cubic meters }\end{array}$ & Federal statistics service \\
\hline $\mathrm{X} 14$ & Average value of the Bank of Russia's key rate & $\%$ & Bank of Russia \\
\hline $\mathrm{X} 15$ & Average Brent oil price & $\begin{array}{c}\text { dollars per } \\
\text { barrel }\end{array}$ & Federal statistics service \\
\hline $\mathrm{X} 16$ & Average URALS oil price & $\begin{array}{c}\text { dollars per } \\
\text { barrel }\end{array}$ & Federal statistics service \\
\hline $\mathrm{X} 17$ & Average value of oil and gas budget revenues & billion rubles & Federal statistics service \\
\hline $\mathrm{X} 18$ & Average value of outstanding loans & million rubles & Bank of Russia \\
\hline $\mathrm{X} 19$ & Average value of the Chinese Yuan exchange rate & for 10 units & Bank of Russia \\
\hline $\mathrm{X} 20$ & Average value of the us dollar exchange rate & per unit & Bank of Russia \\
\hline $\mathrm{X} 21$ & Average value of the Euro exchange rate & per unit & Bank of Russia \\
\hline $\mathrm{X} 22$ & Average value of Brent crude oil futures & USD & Bank of Russia \\
\hline
\end{tabular}

After determining the spectrum of factors that can affect the $\mathrm{Y}$ object under study, a correlation matrix is constructed, that demonstrates the degree of influence of each of the factors on Y. Initially, the number of factors is determined, the correlation with which is more than 0.5 modulo - X1, X2, X5, X8, X11, X13 and $\mathrm{X} 18$. Next, the multicollenarity between the selected factors is determined, which should be less than 0.7 to include the factor in further modeling. Provided that, between the factors, multicolenniality is greater than 0.7 , the factor with the greatest correlation with $\mathrm{Y}$ is selected for further modeling.

\section{RESULTS AND DISCUSSION}

As a result of the correlation analysis, factors such as $\mathrm{X} 8$, X13 and X18 were selected. However, the econometric theory also allows one to accept factors for modeling that logically affect the object under study, avoiding the results of correlation analysis. Based on this, to conduct regression modeling, X16 is added to the selected factors, which logically could have an effect on the level of overdue debt.

Regression modeling considering the selected factors X8, X13, X16 and X18 (Table 3) showed that, despite a sufficient level of determination coefficient (0.9295), the significance of the model according to the Fisher test, the Student's test on the coefficients significance of the regression equation showed that the coefficient at $\mathrm{X} 8$ is not statistically significant, based on which repeated regression modeling was performed, but without the $\mathrm{X} 8$ factor. 
Table 3. Regression modeling without X8 factor

\begin{tabular}{|l|l|}
\hline \multicolumn{2}{|l|}{ Regression statistics } \\
\hline Multiple R & 0,958203 \\
\hline R-square & 0,918154 \\
\hline Normalized R-square & 0,897692 \\
\hline Standard error & 1,198304 \\
\hline Observations & 16 \\
\hline
\end{tabular}

The R-square (coefficient of determination) shows that the investigated $\mathrm{Y}$ object is $91.82 \%$ dependent on the values of the selected factors: X13, X18 and X16
Analysis of variance

\begin{tabular}{|l|l|l|l|l|l|}
\hline & df & SS & MS & F & F Value \\
\hline $\begin{array}{l}\text { Regressio } \\
\mathrm{n}\end{array}$ & 3 & $\begin{array}{l}193,30017 \\
8\end{array}$ & $\begin{array}{l}64,4333 \\
9\end{array}$ & $\begin{array}{l}44,872171 \\
79\end{array}$ & $8,5 \mathrm{E}-07$ \\
\hline $\begin{array}{l}\text { The } \\
\text { remainde } \\
\mathrm{r}\end{array}$ & 1 & $\begin{array}{l}17,231185 \\
4\end{array}$ & $\begin{array}{l}1,43593 \\
2\end{array}$ & & \\
\hline Total & 1 & $\begin{array}{l}210,53136 \\
4\end{array}$ & & & \\
\hline
\end{tabular}

The excess of the calculated value of the Fisher criterion over the table indicates the statistical significance of the entire model

\begin{tabular}{|l|l|l|l|}
\hline & Coefficients & $\begin{array}{l}\text { Standard } \\
\text { error }\end{array}$ & t-statystics \\
\hline Y intersection & 3,985038 & 2,03316888 & 1,960014 \\
\hline X13 & 0,025423 & 0,00980326 & 2,593329 \\
\hline X18 & $-1,1 \mathrm{E}-05$ & $2,0731 \mathrm{E}-06$ & $-5,0865$ \\
\hline X16 & 0,096784 & 0,041889 & 2,310482 \\
\hline
\end{tabular}

Student's criterion on the coefficients significance of the regression equation (tabular value of the criterion $=2.16037$ ) demonstrates the statistical significance of all the coefficients modulo.

Despite a small change in the determination coefficient, a regression model with three factors remains statistically significant according to the Fisher test and the Student's test (coefficients of the regression equation). The equation revealed during regression modeling has the following form (Formula 1):

$$
\mathrm{Y}=3,985038+0,025423 * \mathrm{X} 13+0,096784 * \mathrm{X} 16-
$$

Regression modeling also allowed generating the value of the object $\mathrm{Y}$ under study if it was influenced only by selected factors, as well as the difference between the actual and regression value of the overdue debt level (balances), which are checked for the balances autocorrelation, approximation errors, and homoscedasticity.

The approximation error was higher than $8 \%(27.70 \%)$ a satisfactory value, since it falls in the range of 20$50 \%$. There is no residues autocorrelation, since $\mathrm{k}=8$ falls within the range according to the table values in $\mathrm{k} 1=4 \mathrm{k} 2=14$. The excess of the table value $\mathrm{t}$ over the observed one indicates the residues homoscedasticity (meets the prerequisites of the least square method). 
Based on the calculations performed and a small sample (less than 40), it is advisable to check for residues autocorrelation using the series method. "Rows" are formed with the same characters on the remainder, i.e. the characters that follow one another are formed in brackets in the so-called rows. As a result, these "series" turned out to be $\mathrm{k}=8$. Next, the number of positive deviations $\mathrm{n} 1=9$, the total number of negative deviations $\mathrm{n} 2=7$ is determined. Referring to the table of rows number critical values to determine the presence of autocorrelation at $\alpha=0.05$, it is determined that $\mathrm{k} 1=4$, $\mathrm{k} 2=14$ and it is concluded that there are no residues autocorrelation, since the number of rows is included in this range.

The average approximation error is the average deviation of the calculated values from the actual values, determined by Formula 2, arithmetic mean of relative errors:

$$
\bar{A}=\frac{1}{y}-\sum\left|\frac{y-\hat{y}}{y}\right| \cdot 100 \%
$$

The analysis showed a satisfactory value of the approximation error - $27.70 \%$, which indicates that there is a non-linear dependence of the parameters under consideration.

The Spearman rank correlation test was used to determine heteroscedasticity. When using this test, it is assumed that the variance of the deviations will either increase or decrease with increasing values of $X$. Therefore, for the regression constructed by the leastsquares method, the absolute values of the deviations ei| and xi values will be correlated. The coefficient of rank correlation is determined by the Formula 3:

$$
r_{x, e}=1-6 \cdot \frac{\sum d_{i}^{2}}{n\left(n^{2}-1\right)}
$$

where: di - difference between the ranks xi and |ei|, n number of observations.

And then $\mathrm{t}$ is determined by the Formula 4:

$$
t=\frac{r_{x, e} \sqrt{n-2}}{\sqrt{1-r_{x, e}^{2}}}
$$

Since, as a result of the analysis, the observed statistic value for the three studied factors is less than the critical value calculated from the table of Student's critical distribution points, the hypothesis that the correlation coefficient is equal to zero should be accepted as well as the lack of heteroscedasticity.

Thus, the generated model is forecasted, and at the same time, a point forecast of each of the three selected factors is initially carried out and, based on the obtained values, the level of overdue debts is predicted using the previously identified regression equation, indicating the forecast values of each factor for the corresponding period instead of unknown $\mathrm{X}$.

Forecasted levels of overdue debt for 2021 are presented in Fig 9.

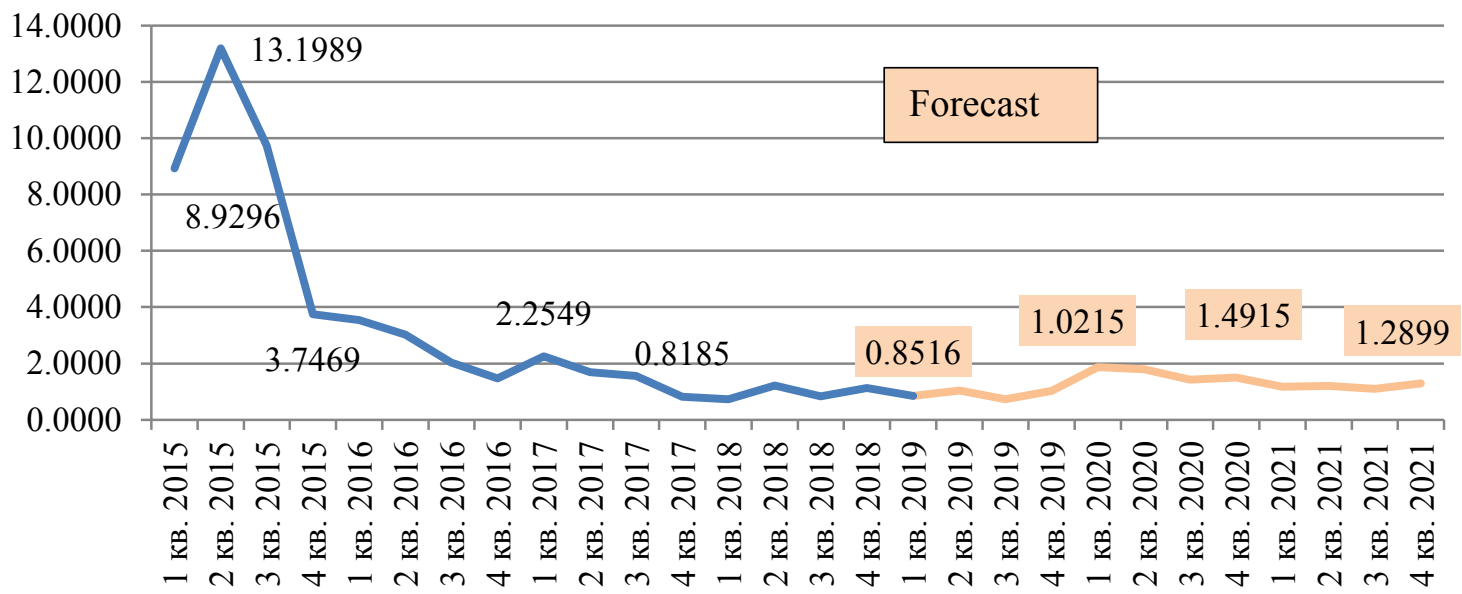

Fig.9. Forecast of the overdue loans level to oil and gas companies in the Russian Federation by the end of 2021 , \%

The forecast of the overdue debt level to Russian oil companies is characterized by a small growth trend with confirmation of the previously set hypothesis. 
International Journal of Engineering Research and Technology. ISSN 0974-3154, Volume 13, Number 11 (2020), pp. $3485-3496$

(C) International Research Publication House. https://dx.doi.org/10.37624/IJERT/13.11.2020.3485-3496

\section{ANALYSIS RESULT}

Since despite the confirmation of the first hypothesis, a certain aspect was identified (the value of the approximation error), there is a need to test the second hypothesis on the potential interest in the oil and gas industry of the Russian Federation by determining the trend of the MOEXOG Moscow Exchange industry.
Thus, the second hypothesis is tested in the same way as the first one: correlation and regression analysis, verification of balances, and prediction of the MOEXOG value under the influence of selected factors (Tables 4-5).

Table 4. Indicators for conducting MOEXOG modeling [12]

\begin{tabular}{|c|c|}
\hline Variable & Description \\
\hline Y & MOEXOG - Moscow Exchange index (oil and gas) at the end of the quarter \\
\hline $\mathrm{X} 1$ & Average crude oil production (including gas condensate), thousand tons \\
\hline $\mathrm{X} 2$ & Average export prices (crude oil), USD per barrel \\
\hline $\mathrm{X} 3$ & Average export prices (petroleum products), USD per barrel \\
\hline $\mathrm{X} 4$ & Average export prices (natural gas), USD per thousand cubic meters \\
\hline $\mathrm{X} 5$ & Average export prices (liquefied natural gas), USD per thousand cubic meters \\
\hline X6 & Average value of Brent crude oil price, dollars per barrel \\
\hline $\mathrm{X} 7$ & Average value of the URALS oil price, dollars per barrel \\
\hline $\mathrm{X} 8$ & Average value of oil and gas budget revenues, billion rubles \\
\hline X9 & The average value of the Chinese Yuan exchange rate, for 10 units. \\
\hline $\mathrm{X} 10$ & Average value of the us dollar exchange rate, per unit \\
\hline $\mathrm{X} 11$ & Average value of the Euro exchange rate, per unit \\
\hline $\mathrm{X} 12$ & Average value of Brent crude oil futures \\
\hline $\mathrm{X} 13$ & Moscow Exchange index, Rel. units at the end of the month (quarter) \\
\hline $\mathrm{X} 14$ & RTS index, tn. units at the end of the month (quarter) \\
\hline $\mathrm{X} 15$ & Moscow Exchange blue chip index, RUB at the end of the quarter \\
\hline
\end{tabular}

Table 5. Regression modeling with selected factors

\begin{tabular}{|c|c|}
\hline \multicolumn{2}{|c|}{ Regression statistics } \\
\hline Multiple R & 0,989190743 \\
\hline R-square & 0,978498326 \\
\hline Normalized R-square & 0,973122908 \\
\hline Standard error & 153,6152628 \\
\hline Observations & 16 \\
\hline
\end{tabular}

The R-square (coefficient of determination) shows that $97.85 \%$ of the studied object $Y$ depends on the values of the selected factors $\mathrm{X} 7$, $\mathrm{X} 10$ and $\mathrm{X} 15$ 


\begin{tabular}{|c|c|c|c|c|c|c|c|}
\hline \multicolumn{7}{|c|}{ Analysis of variance } & \multirow{10}{*}{$\begin{array}{l}\text { The excess of the } \\
\text { calculated value of the } \\
\text { Fisher criterion over } \\
\text { the tabular one } \\
\text { indicates the statistical } \\
\text { significance of the } \\
\text { entire model }\end{array}$} \\
\hline & $d f$ & $S S$ & $M S$ & & & Значимость $F$ & \\
\hline Регрессия & 3 & 12886583,76 & 4295527,92 & 182 & 032 & $2,87111 \mathrm{E}-10$ & \\
\hline Остаток & 12 & 283171,7876 & 23597,649 & & & & \\
\hline \multirow[t]{2}{*}{ Итого } & 15 & 13169755,55 & & & & & \\
\hline & & Coefficients & \multicolumn{2}{|c|}{$\begin{array}{l}\text { Standard } \\
\text { error }\end{array}$} & \multicolumn{2}{|c|}{ t-statystics } & \\
\hline \multicolumn{2}{|c|}{ Y-пересечение } & $-4966,075177$ & \multicolumn{2}{|c|}{705,1868145} & \multicolumn{2}{|c|}{$-7,0422122$} & \\
\hline \multicolumn{2}{|l|}{$\mathrm{X} 7$} & 33,47492684 & \multicolumn{2}{|c|}{6,168077696} & \multicolumn{2}{|c|}{5,4271247} & \\
\hline \multicolumn{2}{|l|}{$\mathrm{X} 10$} & 64,94955917 & \multicolumn{2}{|c|}{11,28202515} & \multicolumn{2}{|c|}{5,75690608} & \\
\hline \multicolumn{2}{|l|}{$\mathrm{X} 15$} & 0,328510119 & \multicolumn{2}{|c|}{0,037439896} & \multicolumn{2}{|c|}{8,77433319} & \\
\hline
\end{tabular}

Regression equation

The Student's criterion of the regression equation coefficients significance (table value of the criterion $=$ 2,16036866) demonstrates the statistical significance of all coefficients modulo.

$$
\mathrm{Y}=-4966,075177+33,474925684 * \mathrm{X} 7+0,649495517 * \mathrm{X} 10+0,328510119 * \mathrm{X} 15
$$

An approximation error below $8 \% \quad(2.23 \%)$ is an excellent value indicating a favorable model. There is no residues autocorrelation, since $\mathrm{k}=10$ falls within the range according to the table values in $k 1=4 \mathrm{k} 2=14$. The excess of the table value $t$ over the observed one indicates the residues homoscedasticity (meets the prerequisites of the least squares method).
As a result, the second hypothesis was confirmed (fig.10) and had more positive modeling results, in contrast to the first, which is an additional confirmation of the feasibility of forming a new tool.

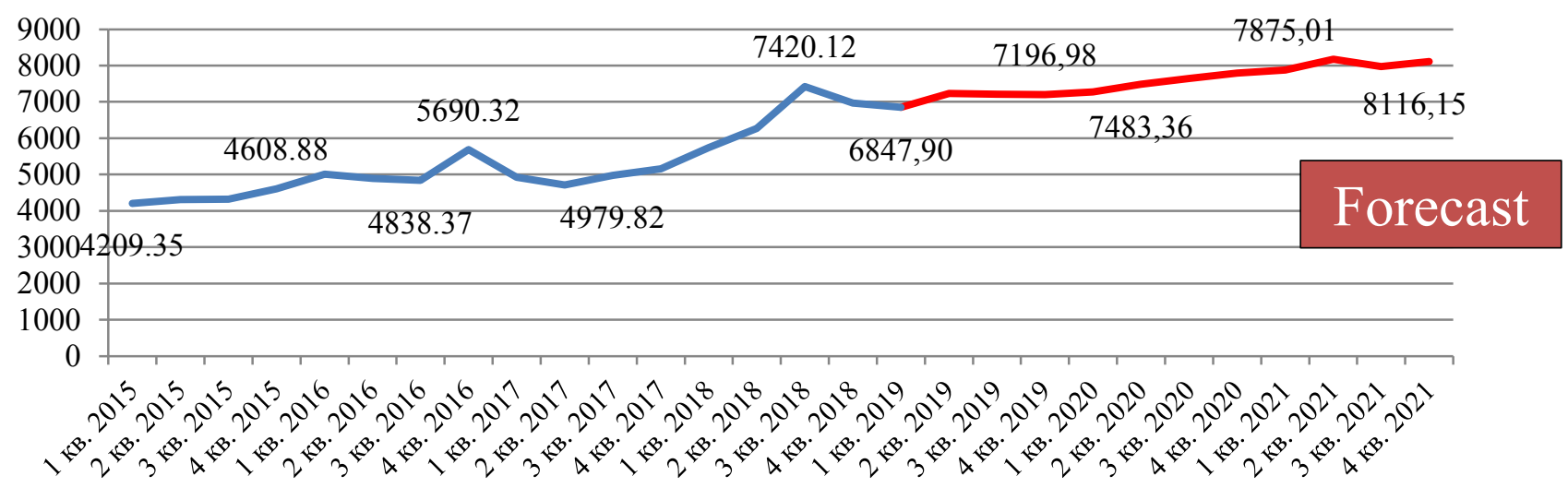

Fig.10. MOEXOG forecast to the end of 2021, RUB.

According to the forecast data, the value of the MOEXOG index is expected to grow, which indicates the investment attractiveness of Russian companies in this industry, as well as the favorable financial position of companies in the market as a whole. 


\section{FINDINGS AND CONCLUSIONS}

Revealing the specifics of financing Russian oil and gas companies, it was noted that this industry is significantly dominated by external sources of financing for operating, in particular, such banking financial and credit technologies as loans and project lending. The Russian oil and gas business practically does not use such an external tool as leasing.

The imposed sanctions against oil and gas companies led to the formation of a certain specificity in the financial and credit technologies used by companies in the form of a reorientation from foreign sources of financing to national ones in the form of increasing volumes of loans and a share in the Russian bond market. Two of these tools, in addition to project financing, investment and syndicated lending, are in modern realities the most common financial and credit technologies. However, the increase in lending also led to an increase in the overdue debts level during the period of exacerbation of the imposed sanctions and confirmation of the non-diversification of the tools used by the oil and gas business, which led to the formation of a hypothesis about the overdue debts increase by the end of 2021 .

\section{ACKNOWLEDGEMENTS}

The work is performed according to the Russian Government Program of Competitive Growth of Kazan Federal University.

\section{REFERENCES}

[1] World Energy Investment 2019. Investing in our energy future / Flagship report - May 2019. Access: https://www.iea.org/wei2019/financing/

[2] Alessandro Blasi Commentary: The Journey of US Light Tight Oil Production Towards a Financially Sustainable Business [e-source] / Alessandro Blasi //Oil industry insight - 2018. - Access: https:/oilindustryinsight.com/oil-gas/opinioncommentary/commentary-the-journey-of-us-lighttight-oil-production-towards-a-financiallysustainable-business/

[3] Investment Analysis: The journey of US light tight oil production towards a financially sustainable business // International Energy Agency - 2018. URL:

https://www.iea.org/newsroom/news/2018/july/inves tment-analysis-the-journey-of-us-light-tight-oilproduction-towards-a-finan.html

[4] Bagautdinova NG, Karasik EA, Safiullin LN, Ismagilova GN. Problems of regulation in financial markets. Journal of Engineering and Applied Sciences. 2017;12(19):4908-4912

[5] Bulatova E, Zakhmatov D, Aliakberova LZ. Key Developments And Trends In Project Finance Market//Academy of Strategic Management Journal. 2016;15:185-190

[6] Comparative characteristics of oil companies [Electronic resource]// Oil\&Gas Russian Journal Access: https://ogjrussia.com/uploads/documents/3843_Razv1_A++.pdf

[7] Bulatova EI, Potapova EA, Fathutdinova RA, Yandiev RC. Monitoring and controlling banking system via financial stability assessment. International transaction journal of engineering management \& Applied sciences \& Technologies. 2019;10(16).

[8] Production of crude oil, natural gas, etc. [Electronic resource] / Statistics // Official website of the Ministry of Energy of the Russian Federation Access mode: https://minenergo.gov.ru/activity/statistic

[9] Statistics of the external sector [Electronic resource]/ Macroeconomic financial statistics // Official website of the Bank of Russia - Access mode: https://www.cbr.ru/statistics/?PrtId=svs

[10] Statistics of the official website of the Ministry of Finance of the Russian Federation [Electronic resource] // Official site of the Ministry of Finance of the Russian Federation - Access mode: https://www.minfin.ru/ru/statistics/

[11] Statistics on the banking system of the Russian Federation [Electronic resource] / Statistics. Official website of the Bank of Russia - Access mode: http://www.cbr.ru/statistics/

[12] Shaidullin R, Bulatova E, Kurmanova L. () Evaluation of financial stability of Russian companies. E3S Web of Conferences. 2019; 110(02044). 